\title{
Özel Dosya: Reflektif
}

\section{Pınar Uyan Semerci}

İçinde olduğumuz 2020 yllı, pandemi sürecinden önce de bir çok belirsizlik ve korkuyu barındırıyordu. Koronavirüs salgını ile beraber yaşam, ilişkiler, ekonomik sorunlar ve her şeyden öte ihtiyaçlar ve haklara erişim hepimizin her gün farklı düzeylerde ve kelimelerle düşündügü, dillendirdiği bir hal aldı. Sosyal bilimin farklı disiplinlerinin ve bu disiplinlerin birbiriyle diyaloğunun bize tutacağı ışığa her zamankinden daha çok ihtiyacımız var. Reflektif işte böyle bir ortamda siz değerli okuyucuları ile buluşurken, ilk sayıya özel çok değerli hocalarımızın kendi araştırmalarını, alanlarını, disiplinlerini, sosyal bilimi ve aslında bilimi değerlendirdikleri çok kıymetli dört yazıyı sizlere sunuyoruz.

Alan Duben, Aydın Uğur, Diane Sunar ve İlter Turan. Yalnızca çalıştıkları disiplinin öğrencileri için değil, araştırmaları, çalışmaları ve düşünceleri ile hepimizin hocası olmuş bu dört kıymetli isim, geçmişten bugüne olan yolculuklarını ve bugünü tecrübeleri ışığında ele alıyorlar. Akademinin yalnızlaştırıcı olabilecek ortamına direnen ve beraber düşünmeyi, üretmeyi, tartışmayı ve en önemlisi beraber merak ederek, öğrenmeyi amaçlayan sosyal bilimcilere, bu ilk sayıya özel dosyayı sunabilmek bizim için çok anlamlı. Alan, Aydın, Diane ve İlter Hoca'yı yakından tanımış olmak, onların araştırmalarını, yorumlarını ve her birinin kendi özgünlüğünü ama ortak bir biçimde "özenle, itina ve merakla" nasıl çalıştıklarını birinci elden gözlemlemiş, beslenmiş sosyal bilimciler olarak, sizlerle onların bu özel sayı için kaleme aldıkları metinleri buluşturabildiğimiz için çok mutluyuz. Bu makalelerin yazım süreci de her bir hocamızla daha yakından zaman geçirme fırsatı yarattı ve yine yeniden süreçteki soruları ve yorumları ile keyifli bir düşünme, öğrenme süreci yaşadık.

Dünyanın ve Türkiye'nin içinde olduğu koşullar ve sorunlar her birimizi farklı şekillerde etkilerken, akademik dünya, özellikle sosyal bilim, birçok açıdan sorgulanabilir bir biçimde hem geleneklerini korumaya hem de yeni dünyaya ve koşullarına adapte olmaya çalışıyor. İşte tam da bu ortamda bu dört kıymetli hocamızın kişisel yolculuklarının izlerini farklı derecelerde içeren bu yazılar, bizleri hem kendi çalışmalarımızla hem de üretilen bilgiye dair eleştirel bir diyaloğa davet ediyor. Hocalarımızdan, birbiriyle de oldukça ilişkili dört başlıkta özetleyebileceğimiz "reflektif” yazılar istedik: İlki kendi araştırmalarına, kendi çalışmalarına ve metotlarına dair bir değerlendirme; ikincisi içinde bulundukları disiplinler ve/ya alt disiplinler açısından alanlarının değerlendirmesi; üçüncüsü hakikat sonrası tartışmaların yapıldığı gü- 
nümüzde sosyal bilime ve daha genel olarak bilime dair görüşleri; ve aslında hepsiyle de ilişkili olarak akademyanın kurumsal yapısı da dahil olmak üzere içinde olunan koşullara/yapılara/ krizlere dair bir refleksiyon... Saydı̆̆ımız bu dört noktaya her bir hocamız, yazılarında kendi tonları,kendi bakış açıları ile farklı vurgularla yer verdi.

Diane Sunar, In Search of Human Nature (İnsan Doğasının Peşinde) başlıklı makalesinde sosyal psikoloji alanında doktora öğrencisi olarak başladığı akademik yolculuğunun zaman içerisinde geçirdiği dönüşümleri aktarıyor. Sunar, 'insan doğasını' anlama çabasının bir yaşam boyu birçok farklı konu ile nasıl kesiştiğini, araştırma deneyimlerinden verdiği derslere etkisini alandaki gelişmelerle de ilişkilendirerek tartışıyor. Alan Duben, 'Almost One of Us': Fieldwork in Turkey 1969-1971 ('Neredeyse Bizden Biri': Türkiye'de Saha Çalışması Yürütmek 1969-1971) adlı makalesinde 1969-71 yıllarında Türkiye'nin siyasal ve sosyal koşullarında ABD'den gelen genç bir antropolog olarak "saha”da olmayı birçok farklı boyutta ele alıyor. İçine girdiği farklı sosyalliklerle yürüttüğü “saha” çalışmasına 2020 yılından bakarak değerlendirirken, hepimizi kendi konumlarımız ve araştırmalarımıza dair bir sorgulamaya da davet ediyor. Duben, "teorik ve metodolojik-epistemolojik ikilemlerle bir hesaplaşma” olarak formüle ettiği makale sahada olan ve/ya saha çalışmasına dair düşünen tüm araştrımacılara ufuk açıcı bir değerlendirme sunuyor. İlter Turan, ise Sosyal Bilimi ve Sosyal Bilimciyi Düşünürken başlıklı makalesinde kendi deneyimlerinden de örneklerle müspet ve sosyal bilimlere dair görüşlerini aktarıyor. Günümüz koşullarında üniversitede alan/meslek seçiminin ötesinde, çok yönlü gelişmeye imkan sağlayacak bir şekilde felsefe, mantık, matematik, edebiyat, sanat gibi temel alanların öğretilmesinin şart olduğunun altını çizerken, kendi yaşam öyküsü ile örtüşür bir biçimde sosyal bilimlere yönelik algıları, bilimin özelliklerini ele alarak tartışıyor. Aydın Uğur, Hakikatin Evini Sular mı Bastı ? Dünyada ve Türkiye’de Bilim, Bilim İnsanları ve Üniversiteye Dair Bir Ufuk Turu başlıklı makalesinde “hakikat” ın her zaman ve her yerde geçerliliğinin sorgulanması ile bilimin geçirdiği dönüşümleri ve bu dönüşümlerin etkisini tartışıyor. Türkiye’deki akademyaya dair önemli tespitlerin yapıldığı makalede, Uğur, parçası olduğu akademyanın bünyesinde birbirinin tam zıddı iki karakter özelliğini "muhafazakarlık ile yenilikçiliği” bir arada barındırmanın çelişkisine dikkat çekiyor.

Reflektif'in amacını, perspektifini gösteren bu dört yazı ve hocalarımızın ilk sayıya özel paneldeki sunumları (https://youtu.be/MH-SR3d830Q), yaşam boyu meraklı öğrenci olmayı seçmiş okuyuculara, ve muhtemel Reflektif yazarlarına, ulaşmamızı kolaylaştıracaktır diye umuyoruz. Uzun soluklu olmasını dilediğimiz bu yolculuğa hocalarımızın kelimeleri ve sesleri ile başlıyor olmak bir şans, bu şansı verdikleri için bir kez de sizlerin önünde teşekkür etmek istiyoruz. Birlikte düşünmeye, eleştirmeye ve öğrenmeye devam etmek dileğiyle... 